\title{
Embrace it or Resist it? Employees' Reception of Corporate Language Policies
}

\author{
Lønsmann, Dorte
}

Document Version

Final published version

Publication date:

2015

License

CC BY-NC-ND

Citation for published version (APA):

Lønsmann, D. (2015). Embrace it or Resist it? Employees' Reception of Corporate Language Policies. Paper presented at 9th International GEM\&L Workshop, Helsinki, Finland.

Link to publication in CBS Research Portal

\section{General rights}

Copyright and moral rights for the publications made accessible in the public portal are retained by the authors and/or other copyright owners and it is a condition of accessing publications that users recognise and abide by the legal requirements associated with these rights.

Take down policy

If you believe that this document breaches copyright please contact us (research.lib@cbs.dk) providing details, and we will remove access to the work immediately and investigate your claim. 


\title{
Embrace it or resist it? Employees' reception of corporate language policies
}

\author{
Dorte Lønsmann \\ Department of International Business Communication, Copenhagen Business School, \\ Denmark
}

\begin{abstract}
Corporate language policies and particularly the use of English as a corporate language have been studied in MNCs for almost two decades now. Despite these volumes of research, very little has been written about the implementation of new language policies. Few studies have examined resistance to or the process of implementing a corporate language, and even fewer have investigated the employee perspective empirically. The present study uses observational and focus group data to investigate reactions to a new corporate language policy in one Danish MNC. The study draws on sociolinguistic stancetaking theory and ethnographic methods and seeks to understand what contextual factors influence employees' stances towards the introduction of English as a corporate language. English language competence, the local linguistic context and different temporal perspectives are found to be key factors. The paper aims to bring the fields of language in international business and linguistic anthropology together in a study of the barriers experienced in companies implementing a new language policy. The paper contributes to the field of language in international business by exploring when and why corporate language policies encounter resistance. As such the results will shed light on the implementation phase of language policy-making.
\end{abstract}

\section{Keywords}

Language policy, corporate language, stancetaking, language competence, focus groups

\section{Introduction}

Corporate language policies and particularly the use of English as a corporate language have been studied in MNCs for almost two decades now. In the field of language in international business, English as a corporate language has been discussed as a barrier and a facilitator (Marschan-Piekkari et al. 1999b), as an instrument of power and status (Charles and Marschan-Piekkari 2002, Marschan-Piekkari et al. 1999a, Neeley 2013, Tange and Lauring 2009) and with a focus on language choice strategies (Steyaert et al. 2011). Sociolinguistic and anthropological linguistic studies have uncovered key factors in language choice (e.g. Kingsley 2013, Lüdi et al. 2010), investigated language ideologies in international business (Angouri and Miglbauer 2014, Lønsmann 2014a, Nekvapil and Sherman 2013, Millar et al. 2013) and shed light on language-based inclusion and exclusion (Lønsmann 2014b). While the 'language in IB' literature has established the existence of language barriers, more anthropologically inclined studies have shown the central role of language ideologies in relation to language choice and to inclusion and exclusion in the workplace. This paper aims to bring the two fields together in a study of the barriers experienced in companies implementing a new language policy. 
Despite the volumes of research on language policy and English as a corporate language, very little has been written about the implementation of new language policies. Few studies have examined resistance to or the process of implementing a corporate language, and even fewer have investigated the employee perspective empirically. Vaara et al. (2005) investigate reactions to the introduction of Swedish and later English as corporate languages in a Finnish company. While their investigation of the power implications of introducing a new corporate language is illuminating, they focus exclusively on the management level. Logemann and Piekkari (2014) investigate language and translation as power sources in HQ-subsidiary relationships in a company undergoing strategic change. They find that translation to the local language can be used as a form of resistance to the shift of power from subsidiaries to headquarters initiated by the new strategy. Interestingly, as time went by, subsidiary managers were able to reclaim power by acquiring competence in the new English 'company speak'. It is noteworthy that this process took about five years, suggesting that language policy implementation should be considered a long-term process. Finally, Bordia and Bordia (2014) present a theoretical framework for understanding the psychological and contextual factors affecting employees' adoption of a corporate language. They distinguish between employees with and without multilingual competences and argue that employees with existing foreign language competences (in any language) will be more open to a corporate language.

In contrast to Bordia and Bordia, the present study uses empirical data to investigate reactions to a new corporate language policy, and in contrast with Vaara et al. and Logemann and Piekkari, focus is on the employee perspective. The central question for the study is: Which factors influence employees' reception of a new language policy? We do not know much about what happens when a company decides to introduce a corporate language, why some employees embrace the change, while others resist it. The study draws on theory and methods from sociolinguistics and linguistic anthropology and seeks to understand what contextual factors influence employees' stances towards the introduction of English as a corporate language. As such the paper aims to contribute to the field of language in international business by exploring when and why corporate language policies encounter resistance. The results will shed light on the implementation phase of language policy-making - an underresearched topic in the field of language and international business. In a time of increasing internationalisation and ensuing linguistic diversity in both larger and smaller organisations, we need new knowledge about the implications of trying to manage this. The aim of this paper is to contribute with knowledge that will increase our understanding of the relationship between language diversity and language policy, but also to contribute with knowledge which will aid the implementation of corporate language policies in organisations.

\section{Theory: Stance}

Theoretically, the study draws on sociolinguistic stancetaking theory as introduced by Jaffe (2009). Jaffe defines stancetaking as 'taking up a position with respect to the form or the content of one's utterance’ (2009: 1). By taking up stances, speakers positions themselves visá-vis their words, their interlocutors and the context. As such speaker stances can be seen as performances through which speakers align or disalign themselves with particular linguistic forms. In this study, focus is on stance as dialogic. This means that stances emerge in interaction as a co-construction between interlocutors (Jaffe 2009: 8-9), which makes it a suitable theoretical lens for focus group data. It also means that attention to uptake is important in an analysis, e.g. in the form of alignment, contestation, or ignoring the stance. 
Stance has to be interpreted with attention to the degree to which the particular context shapes or constrains individual action or expression. In the context of the present study, the organisational context specifies certain roles and their interactional prerogatives. These conventions constitute a framework against which to interpret individual acts of positioning (2009: 12). In Jaffe's theorizing on sociolinguistic stancetaking, stance is viewed as relational. By taking up a stance or position, a speaker brings into relevance a number of associated positions, e.g. by positioning oneself as a expert giving advice, the speaker positions the audience as novices or as needing advice. Such positioning may be collaborative or contested. Furthermore, individual stances are only meaningful in comparison with other possible stances (2009: 14), i.e. stances not taken. Since the main topic of the study is the reception of language policy, the analysis focuses on 'metasociolinguistic stances', i.e. instances in the interaction where speakers take up stances towards language hierarchies and ideologies or toward the assumed connections between language and identity (Jaffe 2009: 17). Such metasociolinguistic stancetaking can be done through e.g. overt commentary, hypercorrection or through patterns of code choice.

Stance is a useful theoretical perspective on focus group data compared to similar concepts such as attitudes or ideologies. Where an individual traditionally is seen as 'having' an attitude, analysing the data in terms of stances allows for a focus on the dialogic, dynamic and changing nature of positioning. One person can express different stances during a conversation as indeed often happens during a focus group, where informants are heard to change their arguments from one point in the interview to the next.

\section{The setting}

The case company is a Danish company where English is being introduced as the corporate language. Danes are generally considered very proficient in English and also consider themselves to be so. 86\% of Danes claim to speak English well enough to have a conversation (followed by German with 47\% and Swedish with 13\%) (Special Eurobarometer 2012). 44\% of those who can speak English rate their English competence as 'very good', with younger people more likely to rate their foreign language competences as 'very good' than older people. English has a strong presence in the everyday lives of the Danes, with 66\% of Danes saying that they use their 'first other language', which is overwhelmingly likely to be English, daily or often (Special Eurobarometer 2012). Receptive use of English is even more frequent, as $90 \%$ of respondents in a large Danish survey claimed to see and hear English every day or every week (Preisler 1999: 33). The same survey also showed that mostly young people who are employed and/or have completed tertiary education speak English, while a large number of respondents with little or no education and most elderly Danes answer that they never speak English.

English is taught in Danish schools from grade 1 and has a strong presence in the educational system up to and including tertiary level, where $20 \%$ of all university programmes are taught in English (Hultgren 2013). In the corporate world, a recent survey finds that just over half of the members of the Confederation of Danish Industry have English as their corporate language (Rühne 2013). While ethnographic studies indicate that English as a corporate language does not mean that Danish is no longer used (see e.g. Lønsmann 2011), the numbers do indicate the strong presence of English in Danish companies at the level of language policy. 
The case company CONSULT (pseudonym) is a Danish-based engineering and consulting company with 12,000 employees and operations in 57 countries. Since the coming of a new CEO in 2012, CONSULT has been on an internationalisation journey with increased international revenue and more outsourcing to India as key strategic priorities. This strategic focus on globalisation and on increased internal collaboration is reflected in the two slogans introduced by the new CEO: 'Stronger together' and 'One company'. The Danish part of the organisation, here pseudonymised as CONSULT DK, has 3,000 employees distributed across the Copenhagen headquarters and 12 regional offices. CONSULT DK has mainly Danish customers and Danish employees.

At the end of 2012, one of the executive directors for CONSULT DK initiated a language strategy project with the aim of implementing English as a corporate language 'for real', as one informant put it. While English had been the corporate language in CONSULT for a number of years, no explicit language strategy or policy existed. In 2013 a group of HR and communication employees were tasked with the new language strategy project. They began their work by 'taking the temperature in the Danish organisation' (quote from interview with communication employee) with regard to the use of English. They did this by carrying out interviews with employees as well as a questionnaire survey. While the aim of management was to make a shift towards more English, specifically to have all top-down communication in English only, the project group found a lot of resistance among the employees and argued for 'a soft transition' where Danish and English would be used in parallel in 2014-2015. From January 2016 all top-down information will be in English only.

\section{Data and methods}

The study is an exploratory case study with data from one company. The primary data for the analysis are three focus group interviews with a total of 15 participants. The analysis also draws on a secondary data set consisting of participant observation in the organisation, three individual interviews with the employees responsible for making and implementing the language policy, and language policy documents. I entered the field in the spring of 2013 where two interviews were conducted with HR employees involved in the language strategy project. In the summer of 2013, I spent a month doing participant observation and interviews in a department in the Copenhagen headquarters (these interviews are not part of the present data set). In 2014 I conducted a follow-up interview with the communication employee responsible for the language strategy project and collected documents related to the introduction of the language strategy. The fieldwork in the company is on-going with the latest subproject focusing on communication between Danish and Indian employees involved in outsourcing.

I decided to use focus groups as one of my methods of data collection because I was interested in how meaning is constructed in interaction. Focus groups are good for generating data on the meanings of actions because they provide access to group norms and processes, as well as to group meanings (Litosseliti 2003). The three focus groups took place in spring 2015. The three participating departments were selected with the aim of ensuring maximum diversity across the groups. After the initial fieldwork in the organisation, the local linguistic context, specifically the opportunity/necessity to use the corporate language was found to be an important factor influencing employees' reception of the language strategy. Another factor was found to be English language competence. Because the opportunity to use English was 
assumed to vary according to geographical placement (in headquarters or outside), I selected one department from the Copenhagen headquarters and two regional offices, one placed centrally in Denmark and one close to the German border.

In each department my contact in the communication department put me in touch with a local contact who then recruited the other participants. Having greater control over the recruitment phase would have been a benefit to the study, but this was not possible since I was entering into three new departments, which I had no detailed knowledge of. When composing focus groups, it is important to ensure a balance between homogeneity and heterogeneity within and across the groups. By only including employees from one department or office in each focus group, I ensured a certain homogeneity in the groups, as well as familiarity among participants. The advantage of this is that participating in a discussion can be a lot easier for people when the group is relatively homogeneous, and they think they know how the other participants will react. By selecting informants who were already working together, participants were operating in a familiar social context, which is also an advantage when you are interested in the norms and beliefs expressed and created in that context. In order to ensure a lively discussion, it is necessary to balance the homogeneity with heterogeneity, however. If the group is too homogeneous there is a risk that the participants will agree too much, leading to a lack of discussion. The groups ended up being heterogeneous in terms of age (ranging from 28-61 years old), gender (5 female and ten male participants) and to a lesser extent job type (thirteen of the fifteen participants were engineers, with five working as project leaders and one as head of department. The two remaining participants worked in supporting functions, and did not have academic degrees). A greater degree of control over the selection process would have allowed me to ensure greater heterogeneity and presumably also for the expression of a bigger range of perspectives.

The data collection followed ethnographic research principles, which mandate a cyclical movement between research question, data collection, and data analysis (Spradley 1979), where the researcher adjusts the research question and interview questions after the initial data collection and data analysis. Accordingly, I had developed an interview guide ahead of the first focus group, which was adjusted and refined between focus groups allowing for greater level of detail in the later interviews. Each focus group lasted between 1,5 and two hours and had five participants. The number of participants was limited by the fact that the interviews took place during working hours, which meant that CONSULT DK was paying for the employees to take time out of their daily work to participate. The focus groups were video and audio recorded, the data was coded for instances of stancetaking, and relevant excerpts transcribed in CLAN ${ }^{1}$. The stance analysis went through three stages. First, sections where participants take a stance towards the new language policy, i.e. the use of more English in the company, were identified and categorised. The three main categories that emerged from this process were 'Embracing English', 'English has to make sense' and 'Resisting English'. In the second stage of the analysis, I looked at the reasons given for each stance, i.e. how do participants justify resisting or embracing the language policy? In the third stage of the analysis, the stances were related to the contextual factors, e.g. local linguistic context and English competence. The results of the analysis are presented in the next section.

\section{Analysis}

${ }^{1}$ See more at http://childes.psy.cmu.edu/clan/. 
The first part of the analysis summarises the three stances towards increased use of English. The second part looks at the relationship between English competence, age and stance towards increased use of English. The third part focuses on the influence of the local linguistic context, while the fourth part of the analysis investigate the importance of different goals and perspectives among the employees.

\section{Embrace it or resist it? Stances towards increased use of English}

The analysis of the focus groups reveals that the expressed stances with respect to increased use of English at work can be categorised into three types, or more accurately, three points on a continuum ranging from positive to negative stances. At the most positive end of the scale, increased use of English is embraced and viewed as unproblematic.

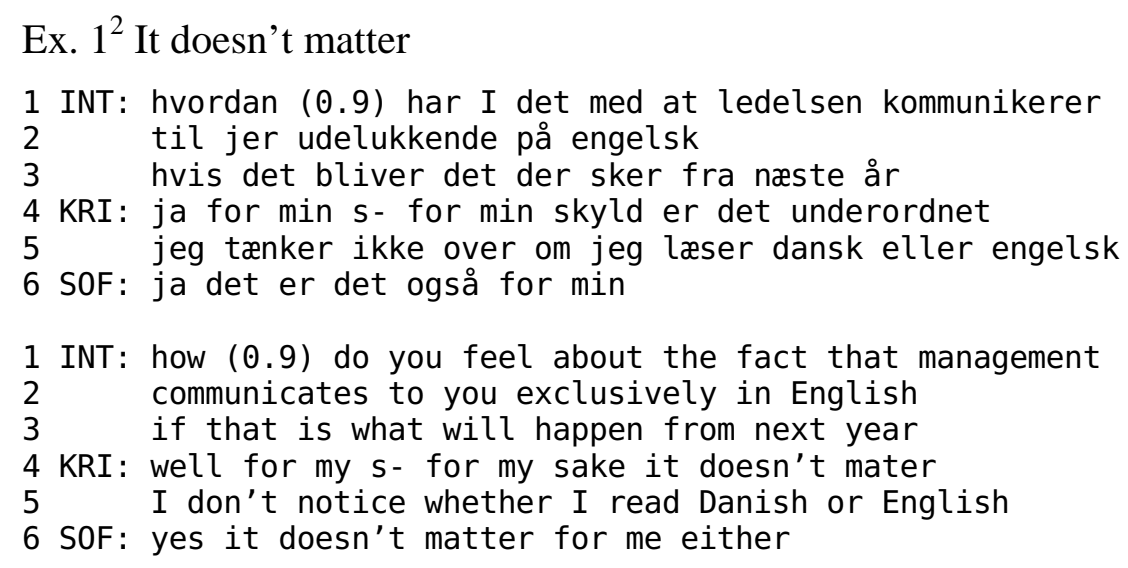

Here the interviewer has introduced a quote from the language strategy, which focuses on the transition from Danish and Danish and English in parallel to the use of 'English only' in written communication. In line 4 Kristina takes an indifferent stance towards the shift by claiming that 'it doesn't matter'. She expands on this in line 5 by saying that she does not even notice the language. Sofie aligns with her stance in line 6. Their stances in lines 4-6 fall into the ‘Embracing English’ stance category.

At the other end of the continuum, stances towards increased use of English are more critical. When the same quote is introduced in another of the focus groups, the initial reaction is very different:

\section{Ex. 2. I couldn't disagree more}

1 INT: hvad synes I om den udmelding

$2(1.2)$

\begin{tabular}{ll}
\hline $\begin{array}{l}2 \text { Transcription conventions: } \\
\text { Speaker ID: }\end{array}$ & SOF \\
Overlapping speech: & 「 okay 1 \\
& L who 」 are not \\
Pause in seconds: & $(0.8)$ \\
Pause shorter than 0.5 sec. & $()$. \\
Prolonged sound: & erm: \\
Smiley voice: & $\odot$ no $\odot$ \\
Irrelevant section left out: & $\ldots$
\end{tabular}




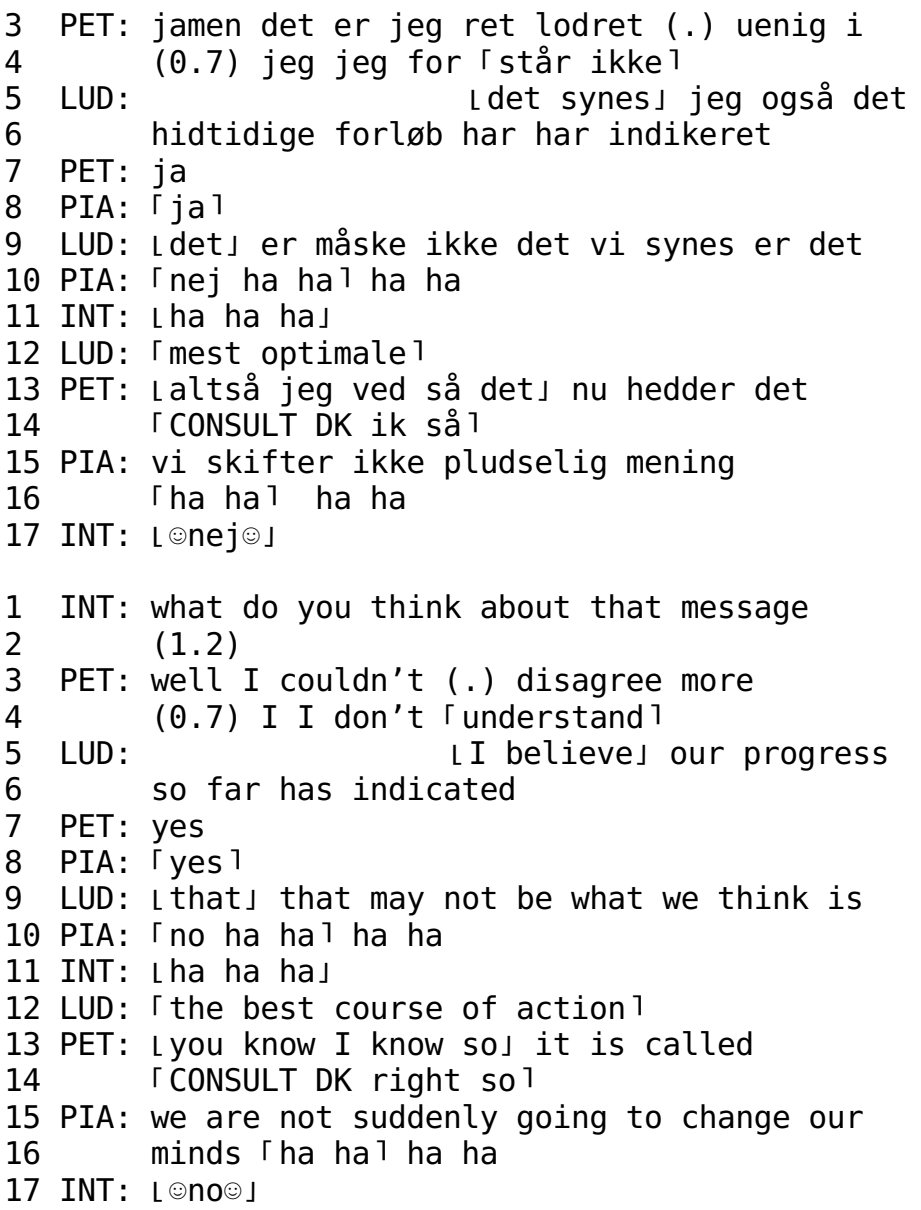

The three participants who speak in this excerpt co-construct a negative stance towards the introduction of 'English only' from the top. In line 2 Peter states that he could not disagree more with the message from the language strategy, and he is immediately backed up by Ludvig, who begins his turn in overlap in line 5. Ludvig alludes to previous parts of the focus group where the participants have made it clear that they are not happy with the increased use of English in CONSULT DK. Pia's laughter in line 10 seems to either frame Ludvig's comment as a joke (which is likely since it is somewhat of an understatement, as their views have been quite clearly expressed already), or perhaps she is laughing because they have been asked again to express their opinion when it has already been made clear. Her turn in line 13 supports this interpretation when she says that they are not going to change their minds on this. Both Ludvig and Pia take stances for the whole group by their use of plural pronouns in lines 9 and 15, and they are not contradicted by the other group members who continue to look at the quote while this interaction takes place. While Peter directly expresses his disalignment with management, Ludvig and Pia resort to humour and indirectness to express theirs. The stances expressed here all belong to the category I call 'Resisting English'.

These two more extreme stances are not the most frequent in the data. The most frequently expressed stance is closer to the middle of the continuum, and can be summarised as 'English has to make sense'. Below is a third example where an informant reacts to the quote about 'English only': 
Ex. 3 It does not always make sense

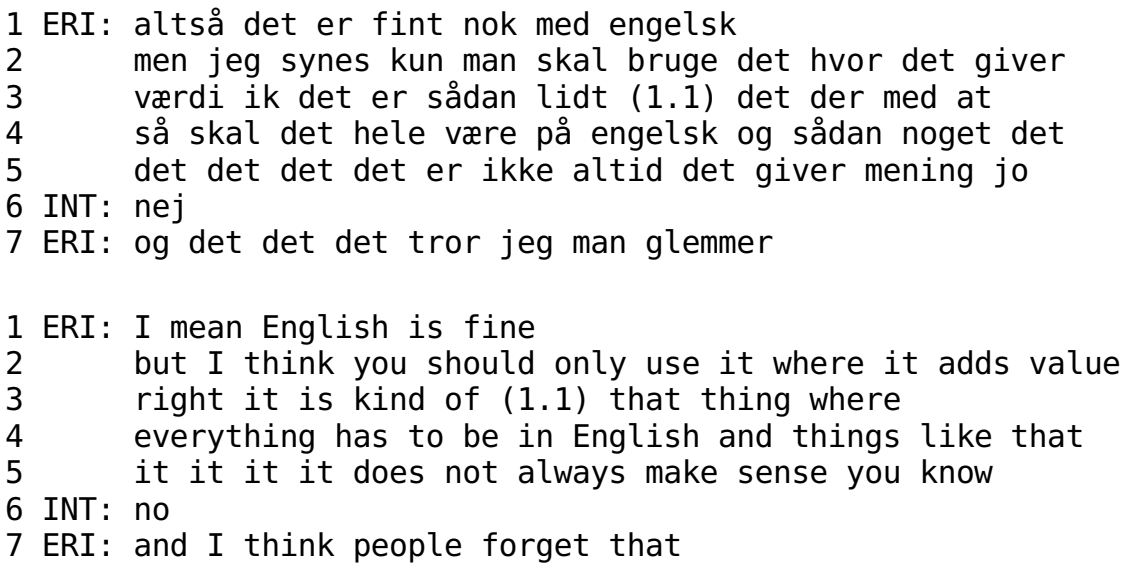

In line 1 Erik aligns with the language strategy and with management, but he immediately adds a caveat. English should only be used where it adds value (line 2), and English does not always make sense (line 5). Both stances represent a disalignment with the idea that 'English only' should be used consistently by management. These two arguments are used repeatedly in all three interviews, and this stance of 'English has to make sense' is taken by most of the informants at some point. Especially the point that English has to make sense ("give mening") is taken up again and again with informants arguing for differentiation between different situations and groups of recipients. The majority of the informants express acceptance of the fact that English should be the corporate language at CONSULT DK, but emphasise heavily that it should only be used where it is relevant. As such this stance category reflects positions both embracing and resisting 'English only'. The next three sections investigate how different stances relate to different contextual factors.

\section{English competence and stance}

In addition to the interview data, I also collected brief questionnaires where informants rated their own foreign language competences on a three-point scale ('basic', 'good', 'very good') ${ }^{3}$. While all 15 informants claim some competence in English, eight informants only have 'basic' English skills. Eight informants report German competence (including the five informants who work near the border), one French, one Spanish, one Kiswahili and one (the only non-native speaker of Danish) listed 'very good' competence in Danish as a foreign language. Table 1 summarises informants' self-assessed foreign language skills:

Table 1. Informants’ foreign language skills.

\footnotetext{
${ }^{3}$ The three-point scale is the same as the one used in Eurobarometer surveys (Special Eurobarometer 2012).
} 


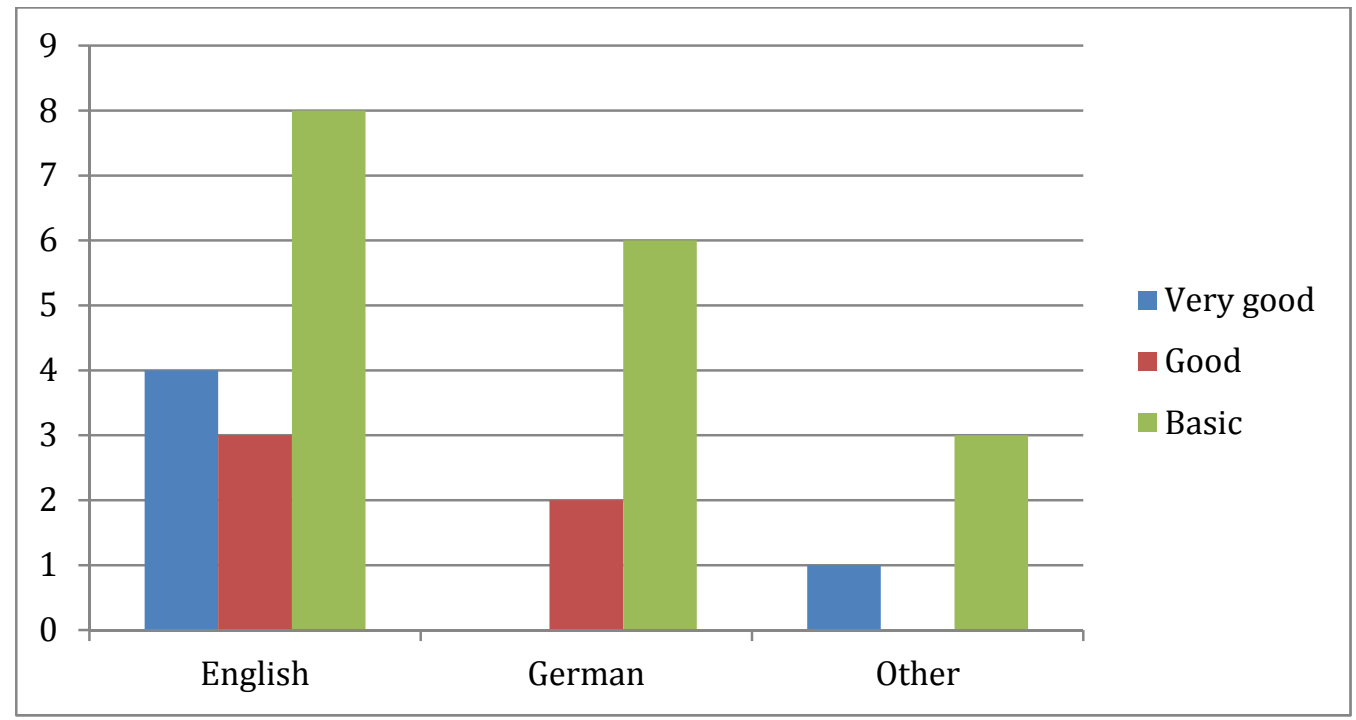

English competence is linked with stancetaking in two different ways. First of all, when the informants take stances of resisting English, they very frequently argue that English is problematic due to competence issues, either for them personally, but also frequently for other employees. In all three focus groups the informants bring up a recent test distributed to all employees in English only as an example of why English is problematic. They had to take the test to see if they were familiar with the company code of conduct, but the language caused problems. Ex. 4 follows immediately after Ex. 1 above where Kristina and Sofie assert that they have no problems with English. Martin follows their assertions with this anecdote:

Ex. 4. It was such a hassle you know.

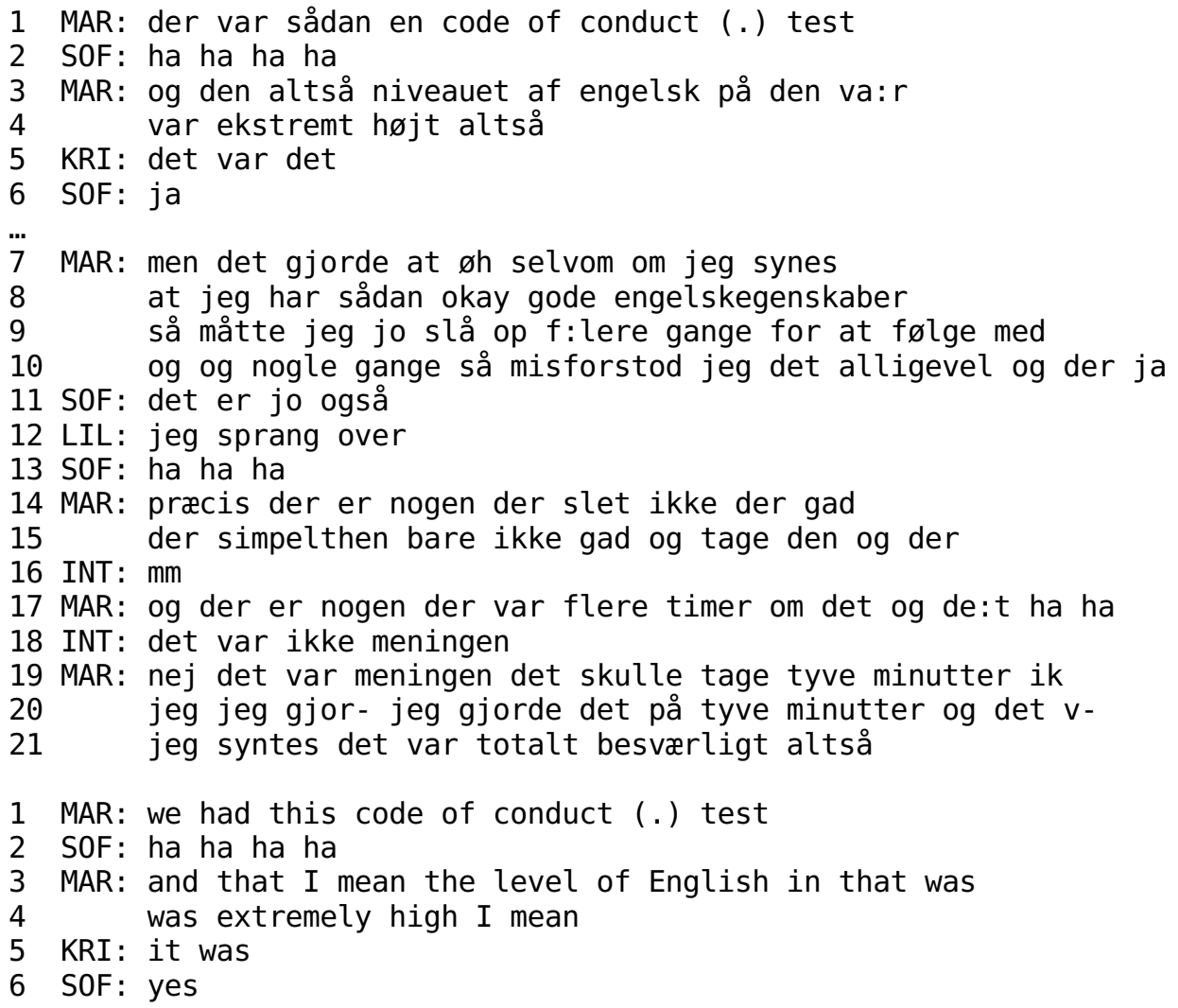




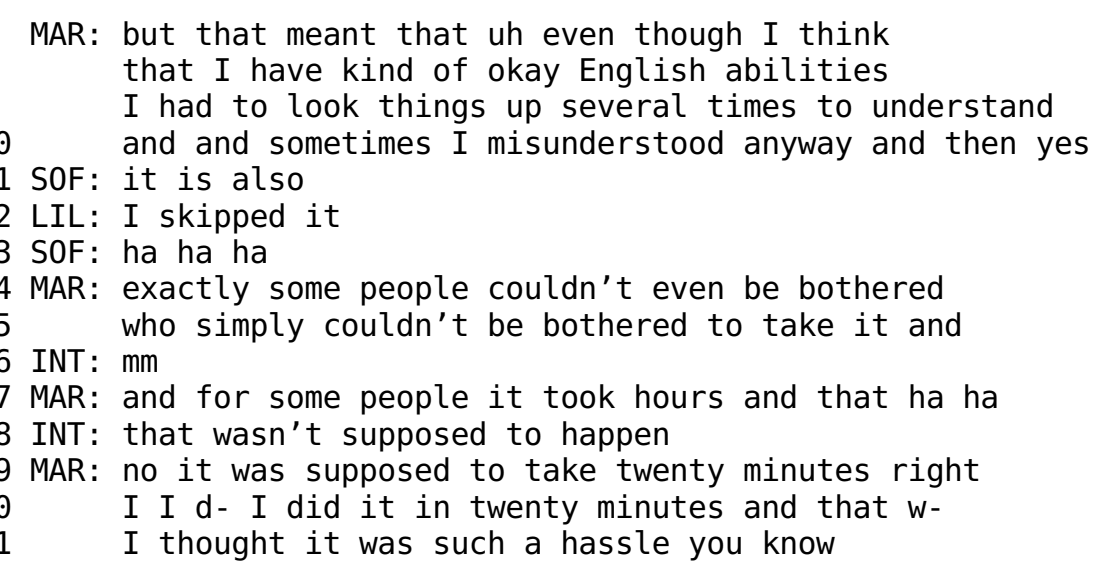

In line 1 Martin brings up the topic of the code of conduct test and explains that the level of English was so high that even with his 'kind of okay' English skills, he had to look things up. Lily chimes in in line 12 that she simply skipped the test, and Martin immediately picks up on this and says that others skipped it too. While Lily does not attribute her skipping the test explicitly to a lack of English competence, this seems to be how Martin understands it when he continues to explain that for others, the test took much longer than it was supposed to, again with implicit reference to the language factor. He finally concludes that even though he managed to take the test in 20 minutes, 'it was such a hassle'. In this and other examples, the informants argue that information in 'English only' in the organisation is problematic because reading material in English is more time-consuming, and because people are more likely to not read information in English. As such, they say, more English will lead to decreased knowledge sharing and a loss of information across the organisation. Another issue commonly raised is that an increase in the use of English will take employees away from their key tasks because of the extra time spent reading material in English.

The code of conduct discussion also provides us with interesting examples of how the same individuals may take different stances in the course of an interaction. In Ex. 1 we saw how Kristina and Sofie both took a stance of embracing English based on their own good English competences. Just two minutes later, after the discussion in Ex. 5, Sofie adds that she found out that she had misunderstood one of the questions and had to look up a word. When Kristina says that she thinks the test should have been available in both Danish and English, Sofie agrees: 'at least if they set such a high English level'. While Kristina seems to have changed her stance because the perspective has changed from her personal experience and competence to considering the competence of her co-workers, Sofie's new stance seems more closely linked with remembering a specific situation where English did cause problems even though she still feels that her 'English skills are fine'. We can see here how the stance an individual takes depends on the immediate interactional context rather than on any ingrained beliefs.

Despite this performative nature of stancetaking, we do see certain stances occurring more frequently in the dialogue of certain types of informants. Informants who rate their own English competence as 'very good' are more likely to take a stance of embracing English unconditionally than informants who rate their competence as 'basic'. The more competent English users talk about the introduction of 'English only' as 'natural', 'fine', 'okay', 'not a problem' and about language choice as 'not important'. Often they explicitly bring their own 
English competences into the equation, e.g. when Kristina cites her experience with presenting in English at international conferences as the reason that language choice is not important for her. At the other end of the continuum, informants who rate their English as 'basic' talk about increased use of English as 'difficult', 'utter nonsense' and 'arrogant'. Informants with basic English competences also link their resistance to English with their own lack of English competences, e.g. when an informant describes himself as 'speaking English on crutches'.

English competence and stance are closely linked with age. Table 2 summarises informants' English competences according to age group:

Table 2. Age group and self-assessed English competences.

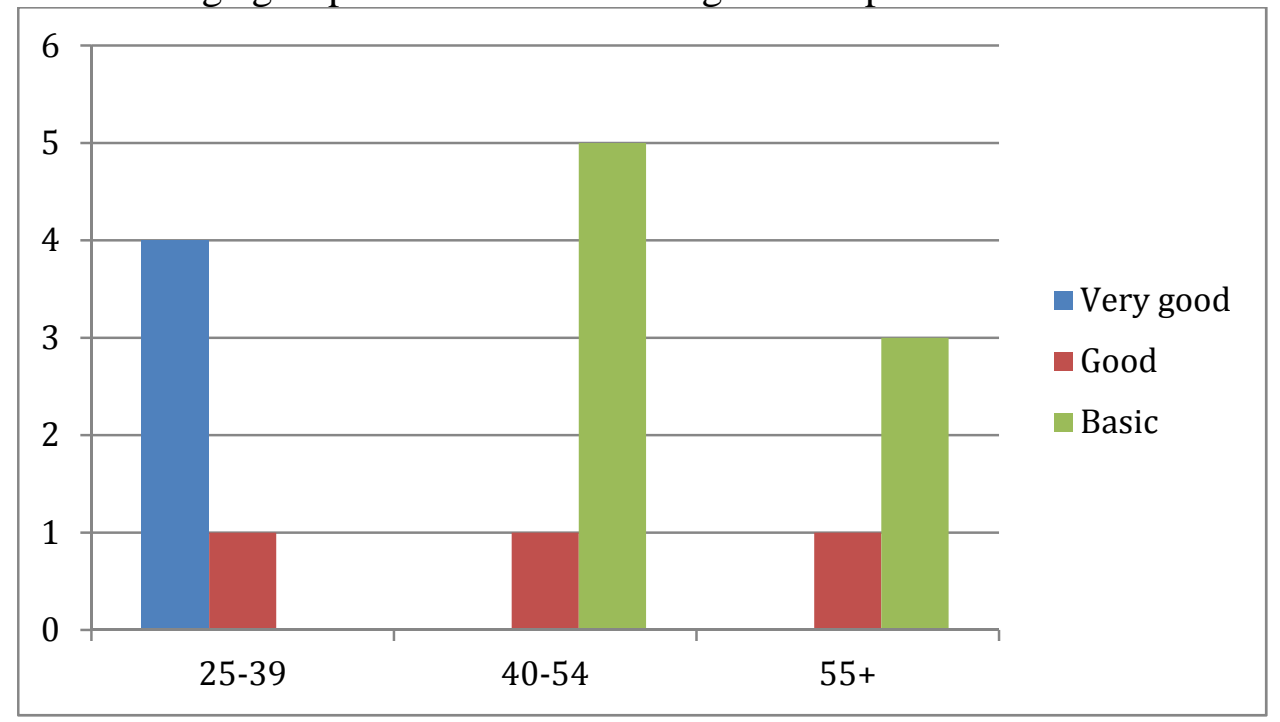

The Table shows that self-rated English competence correlates with age so that younger participants rate their own English higher than older participants. The four participants who rate their own English as 'very good' are all under 40, while the eight participants who rate their English as 'basic' are all over 40. While the self-assessment is not necessarily accurate, Neeley (2013) has shown that participants' self-assessed English competence influences their strategies in relation to language barriers more than their objectively assessed competence, and as such is an important measure for predicting behaviour.

The informants are also aware of this division according to age. Both older and younger participants argue that age is an important factor in relation to English competence and readiness to embrace English. A frequent argument is that age interacts with educational background so that English is more accessible to the younger engineers (under 30) who have as a minimum the master level of their education in English, and much less accessible to the older generation who have had their entire education in Danish. The younger participants have thus been socialized into an English-speaking context before they came into the job market, while the older participants have to adjust to the shift. The close relationship between age, education and language competence means that younger employees without academic degrees may also have problems with English since they are not used to an English-speaking context. This is supported by anecdotal evidence in the focus group data. 


\section{The local linguistic context}

The local linguistic context is another factor influencing employees' stances towards the introduction of 'English only'. While I planned focus groups in three geographically dispersed departments to investigate the differences between them, the three departments proved to have very similar linguistic contexts. In all three departments all employees are Danish-speaking. The majority is native Danes, but the few immigrants all speak Danish at work. As engineers, most of my informants work on construction projects where they come into contact with customers and collaborators on a weekly, if not daily basis. By far the larger part of these projects is with Danish customers in Denmark. In addition to the customers, the engineers also have to communicate with building caretakers, construction workers and foremen, and this takes place in Danish. If some of them cannot speak Danish, they are equally unlikely to speak English, as in the case of the Polish construction workers the informants mention. English is used primarily to read information from top management, while most of my informants speak English only rarely. Some informants occasionally work with non-Danish-speaking colleagues in other departments in Denmark, and two informants have had some experience working on international projects, but these are few and far between. So while English is used actively by some informants, it is only a minority, and only infrequently.

This primarily Danish-speaking local context plays an important role in informants' argumentation around the use of more English. In one example, the practice of sending out emails in English or both English and Danish is criticized by two informants who argue that the use of English should be differentiated, e.g. by sending out two emails, one in Danish for Danish employees and one in English for the rest. 'English only' communication from CONSULT DK management is a central point in the language strategy, but it also includes a section about training, which has the line "The more you practice, the better you get" emphasised in italics. When I present this to the informants in a focusing exercise, several of them react in a similar way. While conceding that practicing is indeed the best way to improve your English competence, they argue that they do not have the need or the opportunity to do so.

\section{Ex. 5 You don't need it in your daily work}

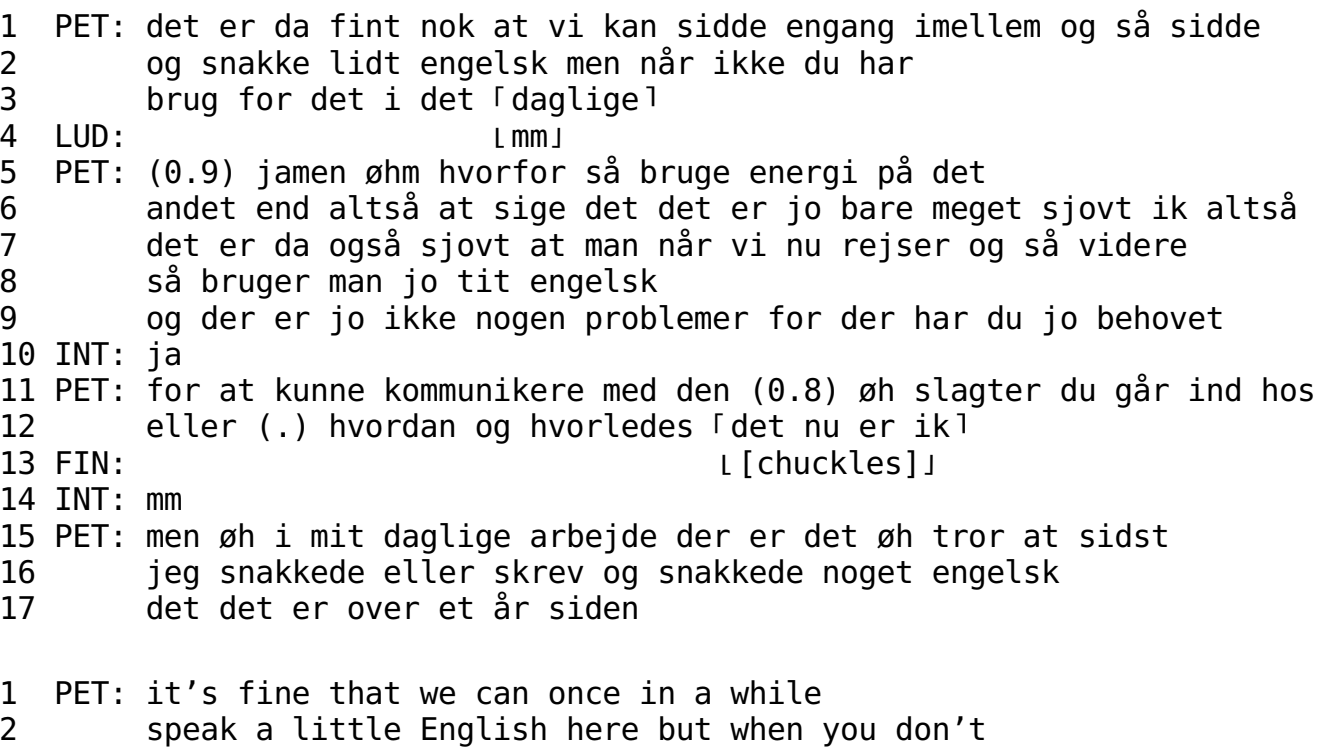




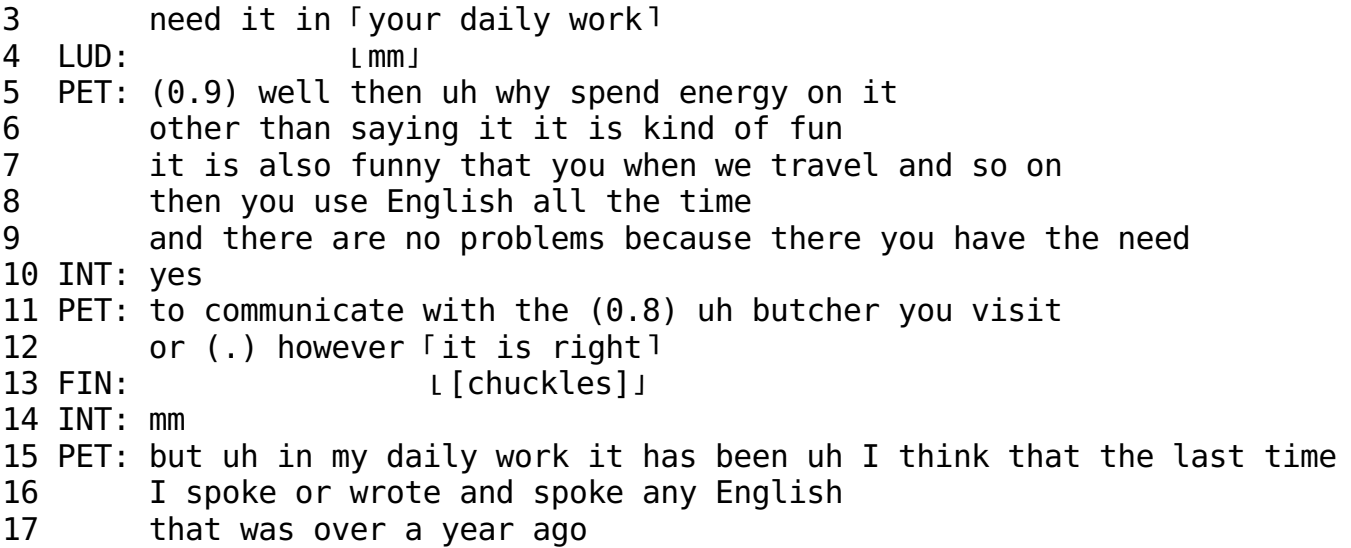

When Peter in line 1 says that 'it's fine that we can once in a while speak a little English', he points around the table to indicate his colleagues or perhaps the situational context of them sitting around the table together. He seems to imply that they could potentially practice English in a similar situation. His comment immediately after seems to contradict the 'fine', however, as he argues that since they do not need English for their work, they should not waste their energy practising it. He contrasts this with travelling on holiday where speaking English is not a problem because 'there you have the need'. It is not that Peter objects to using English in general, but he objects to having to practice when there is no need to use it. Similarly in one of the other focus groups, an informant argues that unless you work on an international project, 'the situation isn't there' and the use of English is 'artificial'. In these and other examples the informants point to their Danish customers, Danish colleagues and the geographical location in regional offices as reasons against the use of more English. They are in favour of English if it makes sense, but it does not make sense in the context of a regional office with Danish employees and customers.

\section{Immediate vs. strategic perspective}

One further factor influencing stances towards English is the temporal perspective taken by employees. While all informants agree that there is no immediate need for English in their departments at present, some informants take a more positive stance towards English when they consider a long-term strategic perspective. Again, the argument 'English has to make sense' is central. Even if English is not needed here and now, it would make sense to introduce it into the organisation in order to fulfil strategic goals, as Erik argues in Ex. 6:

Ex. 6. It is fine when you have that ambition.

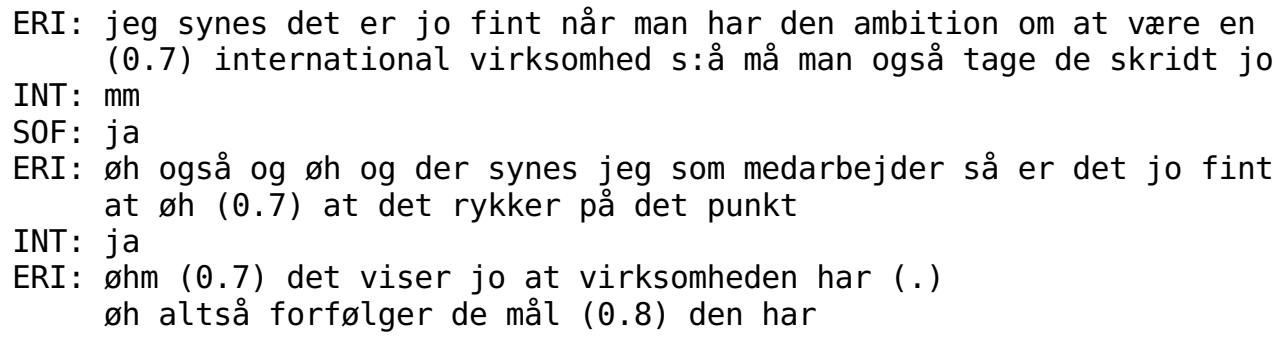


5 ERI: uh also and uh as an employee I think it is good

6 that uh $(0.7)$ that something is happening in that area

7 INT: yes

8 ERI: um $(0.7)$ it shows that the company has (.)

9 uh pursues the goals $(0.8)$ that it has

Erik here considers the new language strategy in relation to the company's internationalisation strategy, and from this perspective, he has no problems embracing it (despite his reservations in Ex. 3). One question that comes to mind is why CONSULT DK is introducing English as a corporate language when there is no immediate need (according to these informants). The answer has to be found exactly in the long-term strategic perspective taken by Erik: CONSULT wants to be an international company, and English is the way to get there (for an elaboration on this see Lønsmann and Mortensen (2015)). One concrete reason for the strategic need for English is given by the informant who says that English makes outsourcing to India possible, and 'that is the whole idea'. Both he and Erik align with the stance expressed by management in the language strategy, i.e. that English is an important part of the internationalisation process. By taking the long-term strategic perspective, it is possible for some employees to take a positive stance towards English because in this perspective English does make sense.

For employees who focus on the short-term perspective, or who do not see themselves as a part of the internationalisation journey, English is harder to accept. Ludvig makes the case here in Ex. 7:

Ex. 7. I would consider getting a hotdog stand.

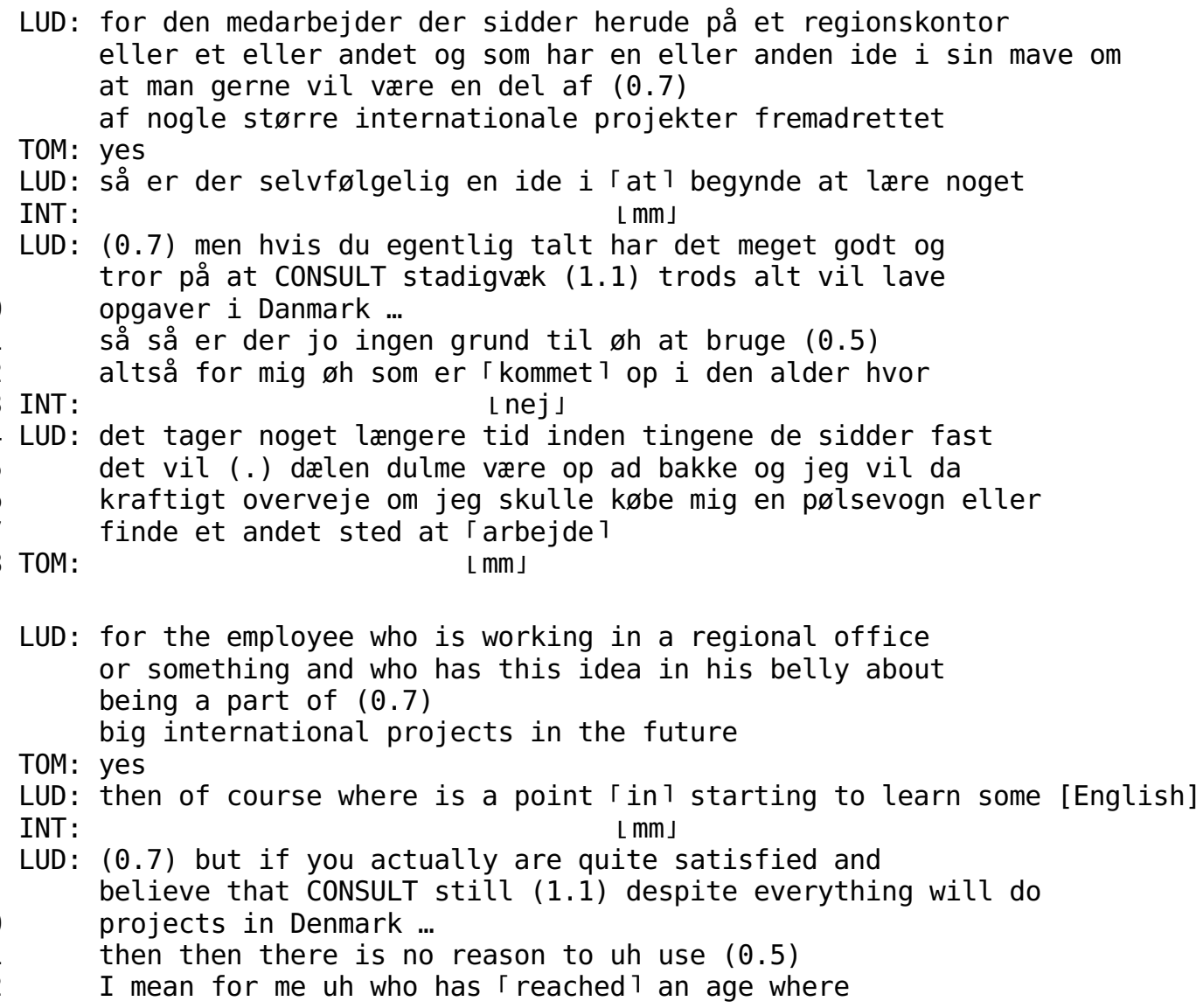


13 INT:

14 LUD: it takes longer to make things stick

15

16

17

18 TOM
(.) it would be uphill darn it and I would

seriously consider whether to buy a hotdog stand or

find another place to 「work 1

$\lfloor\mathrm{mm}\rfloor$

In contrast with Erik above who focuses on the organisational strategy, Ludvig focuses on the individual level. He also considers the long-term perspective, however. Ludvig agrees that learning (more) English would make sense for those employees interested in working on international projects in the future (and Tom emphatically agrees in line 5, using the English 'yes' in a rare codeswitch). Ludvig does not, however, have any international ambitions himself. Instead he positions himself in the group of employees who 'are quite satisfied and believe that CONSULT still despite everything will do projects in Denmark' (lines 8-9). As such he sees no reason to start working on his English and says he will resist it to the point of finding another job. Ludvig also makes age a relevant factor in relation to the long-term perspective, as do other older informants. While younger informants tend to be more open towards making changes in order to fit into CONSULT in the future, e.g. by improving their English, older informants are typically more hesitant to embrace the change. The younger employees seem to accept that they will have to adapt in a number of ways to keep up with developments, including linguistic developments. Employees nearing retirement have the option of leaving the workforce altogether if demands increase beyond what is tolerable. Ambition also plays a role here. Employees who want to move on to bigger projects and more responsibility will focus on the individual strategic relevance of English and embrace it for that reason, while employees who either have already reached a management position or who have no ambitions to move up in the organisation focus on the immediate situation where they find no reason to embrace English. Again this comes back to the point that English has to make sense, if not now then at least in the long term. Hence, the short-term vs. long-term, or immediate vs. strategic, perspective becomes another factor influencing how employees react to the new language strategy.

\section{Discussion and conclusion}

A recent study from the international business literature examines employees' reception of corporate language changes. With a focus on linguistic identity, Bordia and Bordia (2014) present a theoretical framework for understanding the psychological and contextual factors affecting employees' adoption of a corporate language. Central in Bordia and Bordia is the distinction between individuals who have existing foreign language competences and hence what they term a multilingual identity, and individuals without such competences and hence a monolingual identity. It is argued that employees with existing foreign language competences will be more open to a corporate language (2014: 5), even if that corporate language does not match their existing language competences. In the present data all employees have existing foreign language competence in the corporate language, and the majority also in one or two other languages. Still, the results show that the employees take a range of stances from resisting to embracing English. This indicates that the binary categorisation of individuals into multilingual and monolingual identities used by Bordia and Bordia masks the complexity and range of different stances taken by employees. Even in a sociolinguistic environment like the Danish society where individuals are routinely exposed to foreign languages, some individuals will be more open to the adoption of a foreign language as the corporate language than others. Bordia and Bordia's proposition that competence in any foreign language will 
make employees more open to the corporate language lacks empirical evidence as of yet, and seems generally unlikely. Instead, it seems likely that strong language competence in Spanish or German, for example, would make employees less likely to embrace English as a corporate language, not more so, as that would decrease their own linguistic capital (Bourdieu 1991).

The present study shows the advantage of using sociolinguistic stancetaking theory to investigate employees' reception of organisational changes, including changes in language policy. The analysis reveals stancetaking to be a dynamic and dialogic process where individuals may take different stances to the same object during an interaction. Stances change for instance when short-term vs. long-term perspectives are considered, or when personal language competences are held up against those of one’s co-workers.

While previous studies have shown how new language policies lead to new power dynamics in an organisation (Logemann and Piekkari 2014, Vaara et al. 2005), this study focuses on how employees react to the introduction of a new policy of 'English only' from the top. The study finds that employees take three different types of stances: embracing English, resisting English or a middle position where English is embraced as long as it makes sense, i.e. is relevant in the local linguistic context. The analysis of 'who takes which stances when' reveals that although the same individual may take different stances during an interaction, English competence, age and education interact, so that younger informants who were educated in English and rate their own English competence as 'very good' are most ready to embrace English. While this is not surprising, it does suggest that age alone is perhaps not the best indicator of neither language competence nor readiness to embrace English. Instead educational background and exposure to an English-speaking study environment should be taken into account as well. This finding will have implications especially for blue-collar workplaces where also younger employees may resist English because they do not have the necessary competences.

The local linguistic context proved to be a very influential factor in employees' reception of the new language strategy. Following the argument that 'English has to make sense', employees working in a Danish linguistic environment with Danish co-workers and Danish customers frequently took a stance of resisting English. Those employees who were able to take a long-term strategic perspective found it easier to accept the introduction of more English since they could make English make sense by considering a future need, either in the organisation in general or in their own career path.

To sum up, in answer to the research question we can see that English competence, age, educational background, the local linguistic context, and employee perspective on long-term strategy vs. short-term daily interactions are key factors influencing employees' reception of the new language strategy. These results suggest that new language policies are likely to be resisted when they are introduced more to support a long-term strategic goal than because of an immediate need in the daily life of employees. For employees to embrace a new policy, it has to make sense, i.e. they have to see the immediate relevance of the changes they are being asked to make. While some employees are able to take a long-term strategic perspective, and thus can see that the policy makes sense from that perspective, others focus much more narrowly on their own work and their own customers and will have a difficult time embracing the change. 
For companies introducing new language policies, these results mean that management needs to take into consideration the variety of local linguistic contexts employees navigate in. What makes sense in one part of the organisation does not necessarily make sense in another part. For such policies to be implemented successfully, management will have to differentiate between these different contexts, either in the communication about the new policy or ideally - in the degree to which and pace with which the new policy is implemented. Furthermore, management needs to consider the relationship between the strategic goal of the policy and the practical implementation of the policy. In the case of CONSULT, the strategic goal is to increase international collaboration internally in the company, particularly in the form of outsourcing. While increased use of English is necessary to facilitate these processes, the question is whether a policy (and practice) of top management communicating to Danish employees in 'English only' is the best way to get there. Increased focus on the use of English in those contexts where it is necessary, e.g. when employees have to communicate across borders, seems a more fruitful avenue to pursue. Finally, management needs to be aware that their goals do not necessarily align with employee goals. While management operates with a long-term strategic perspective (in which the new policy clearly makes sense), many employees focus primarily on the day-to-day goals of completing their tasks and finishing their projects within the set deadlines. From this perspective, the introduction of organisational changes is more likely to throw a wrench in the works than to aid employees in reaching their goals. As a consequence, employees are likely to resist the change.

\section{References}

Angouri J and Miglbauer M (2014) 'And then we summarise in English for the others': The lived experience of the multilingual workplace. Multilingua 33(1-2): 147-172.

Bordia S and Bordia P (2014) Employees' willingness to adopt a foreign functional language in multilingual organizations: The role of linguistic identity. Journal of International Business Studies: 46(4), 415-428.

Bourdieu P (1991) Language and symbolic power. JB Thompson (ed.). Cambridge: Polity Press.

Charles M and Marschan-Piekkari R (2002) Language training for enhanced horizontal communication - a challenge for MNCs. Business Communication Quarterly 65(2): 929.

Hultgren, A. K. (2013). Parallelsproglighed på danske universiteter: en status rapport 2013.[Parallellingualism at Danish Universities: A Status Report 2013].

Jaffe, A. (Ed.). (2009). Stance: sociolinguistic perspectives. Oxford: Oxford University Press.

Kingsley, L. (2013). "Language choice in multilingual encounters in transnational workplaces”, Journal of Multilingual and Multicultural Development, 34(6), pp. 533548.

Litosseliti, L. (2003). Using focus groups in research. A\&C Black.

Logemann, M., \& Piekkari, R. (2015). Localize or local lies? The power of language and translation in the multinational corporation. Critical Perspectives on International Business, 11(1), pp. 30-53.

Lønsmann, D. (2011). English as a Corporate Language. Language Choice and Language Ideologies in an International Company in Denmark. Roskilde University: Department of Culture and Identity.

Lønsmann, D. (2014a). "Language ideologies in a Danish company with English as a corporate language: 'It has to be English'”, Journal of Multilingual and Multicultural Development. 
Lønsmann, D. (2014b). "Linguistic diversity in the international workplace: language ideologies and processes of exclusion”, Multilingua, 33(1-2), pp. 89-116.

Lønsmann, D. \& J. Mortensen. (2015). "Language, power and policy in a transient multilingual workplace”. Paper presented at iMean4, Warwick University, 10 April 2015.

Lüdi, G., Höchle, K. \& Yanaprasart, P. (2010). "Plurilingual practices at multilingual workplaces”, In Meyer, B. \& Apfelbaum, B. (eds.), Multilingualism at Work, pp. 211234. Amsterdam/Philadelphia: John Benjamins.

Marschan-Piekkari, R., Welch, D. \& Welch, L. (1999a). “Adopting a common corporate language: IHRM implications”, International Journal of Human Resource Management, 10(3), pp. 377-390.

Marschan-Piekkari, R., Welch, D. \& Welch, L. (1999b). "In the shadow: the impact of language on structure, power and communication in the multinational”, International Business Review, 8, pp. 421-40.

Millar, S., Cifuentes, S. \& Jensen, A. (2013). “A social representational perspective on languages and their management in the Danish corporate sector”. In Berthoud, A.-C., Grin, F. \& Lüdi, G. (eds.), Exploring the Dynamics of Multilingualism. The DYLAN Project, pp. 101-120. Amsterdam: John Benjamins.

Neeley, T. (2013). "Language matters: Status loss and achieved status distinctions in global organizations”, Organization Science, 24(2), pp. 476-497.

Nekvapil, J. \& Sherman, T. (2013). "Language ideologies and linguistic practices: The case of multinational companies in Central Europe”. In Barát, E., Studer, P. \& Nekvapil, J. (eds.), Ideological Conceptualizations of Language: Discourses of Linguistic Diversity, pp. 85-117. Frankfurt am Main: Peter Lang.

Preisler, B. (1999). Danskerne og det engelske sprog. [The Danes and the English Language] Roskilde: Roskilde Universitetsforlag.

Rühne, F. H. (2013). "Internationalisering får engelsk til at buldre frem i danske virksomheder. Berlingske, 5. november, Business.

Special Eurobarometer 386. 2012. Europeans and their languages. European Commision.

Spradley, J. P. (1979). The Ethnographic Interview. New York: Holt, Rinehart and Winston.

Steyaert, C., Ostendorp, A. \& Gaibrois, C. (2011). "Multilingual organizations as 'linguascapes': Negotiating the position of English through discursive practices", Journal of World Business, 46(3), pp. 270-278.

Tange, H. \& Lauring, J. (2009). "Language management and social interaction within the multilingual workplace”, Journal of Communication Management, 13(3), pp. 218-32.

Vaara, E., Tienari, J., Piekkari, R., \& Säntti, R. (2005). Language and the circuits of power in a merging multinational corporation. Journal of Management Studies, 42(3), 595-623. 